\title{
Tarik Pasar, Kreasi Nilai dan Keunikan Sumber Daya untuk Meningkatkan Keunggulan Bersaing Serta Implikasinya Terhadap Kinerja Rumah Sakit Umum Swasta di Jawa Barat
}

\author{
Oleh \\ Novi Kadarini Rahayu \\ Dosen Tetap STIE Ekuitas \\ email: trengginasina@gmail.com
}

\begin{abstract}
ABSTRAK
Industri rumah sakit saat ini bukan lagi semata-mata penyediaan layanan publik, namun sudah menjadi ranah komersial. Tingginya permintaan jasa pelayanan rumah sakit dan regulasi yang baru tentang pendirian rumah sakit meningkatkan daya tarik industri rumah sakit. Tingginya potensi dan daya tarik pasar industri rumah sakit sayangnya belum direspon optimal oleh pelaku industri. Penelitian ini dilakukan untuk menjawab bagaimana pengaruh daya tarik pasar, kreasi nilai dan keunikan sumber daya sebagai variabel laten eksogen terhadap kinerja rumah sakit umum swasta di Provinsi Jawa Barat melalui keunggulan bersaing. Uji verifikatif menunjukkan bahwa secara simultan daya tarik pasar, kreasi nilai, dan keunikan sumber daya berpengaruh terhadap keunggulan bersaing. Secara parsial, diantara ketiga variabel laten eksogen, kreasi nilai tidak berpengaruh terhadap keunggulan bersaing. Di samping itu, melalui keunggulan bersaing, daya tarik pasar, kreasi nilai, dan keunikan sumber daya juga berpengaruh terhadap kinerja. Dari temuan penelitian ini, rumah sakit umum swasta di Provinsi Jawa Barat disarankan untuk mengoptimalkan kreasi nilai, meningkatkan keunikan sumber daya, meningkatkan keunggulan bersaing dan juga kinerja. Penelitian selanjutnya disarankan agar melibatkan variabel lain, seperti model kepemimpinan atau perilaku organisasi, untuk menguatkan pengaruh daya tarik pasar dan keunikan sumber daya terhadap keunggulan bersaing dan kinerja rumah sakit umum swasta di Provinsi Jawa Barat.
\end{abstract}

Kata kunci: daya tarik pasar, kreasi nilai.

\section{ABSTRACT}

The hospital industry is need time solely the provision of services, but the hospital industry has become the realm of commercial. The high demand for hospital services and the new regulation on the establishment of hospital raise the attractiveness's hospital. This research to verify the influence of market attractiveness, value creation with uniqueness of resources on competitive advantage of private general hospitals in the West Java, both partially and simultaneously and its impact on hoshospital performance. The findings reveal that the market attractiveness, value creation with uniqueness of resources affect the competitive advantage simultaneously. Meanwhile, partially, among these three variables, the value creation does not affect the competitive advantage. Additionally, through a competitive advantage, the market attractiveness, the value creation, also the uniqueness of the resources affect the performance. We suggest that the private general hospitals in West Java optimize value creation, create uniqueness of resources, enhance competitive advantage also gain better performance. We recommend further research for involving other variables, such as leadership style or organization behavior, in order to strengthen the influence of market attractiveness, uniqueness of resources on competitive advantage also performance of the private general hospitals in West Java.

Keywords: market attractiveness, value creation. 


\section{PENDAHULUAN}

Pelayanan rumah sakit, khususnya rumah sakit umum swasta di Provinsi Jawa Barat, nampaknya belum ditunjang dengan kinerja yang maksimal. Hal ini bisa dicermati dari kinerja operasional rumah sakit.

Prestasi rumah sakit berujung pada efisiensi yang tercermin misalnya pada angka tingkat hunian tempat tidur (BOR) yang merupakan perbandingan antara jumlah pasien rawat inap dengan jumlah tempat perawatan yang tersedia selama setahun, waktu antara tempat tidur kosong (TOI) dan average lama pasien dirawat (LOS).

Dari sisi jumlah kunjungan, penurunan tingkat kunjungan juga merupakan gambaran rendahnya kinerja . Rendahnya BOR dan tingginya TOI disertai dengan penurunan kunjungan jumlah rawat jalan akan menimbulkan penurunan pendapatan farmasi dan pendapatan unit penunjang lainnya sehingga pada akhirnya mempengaruhi kinerja keuangan.

Rendahnya kinerja rumah sakit juga ditunjukkan oleh beragamnya keluhan pelanggan rumah sakit, informasi/pelayanan, kenyamanan, tidak memenuhi prosedur, dokter tidak profesional, sarana rumah sakit dan administrasi/pembayaran.

Rumah sakit harus memberikan pelayanan yang sesuai standar rumah sakit sehingga dapat meraih keunggulan bersaing. Hal ini sangat penting agar penduduk Indonesia percaya bahwa mutu rumah sakit di Indonesia baik/lebih baik daripada luar negri khususnya negara tetangga.

Jika dikaitkan dengan keluhan pelanggan, fenomena tersebut diatas mencerminkan rumah sakit belum sepenuhnya memahami kebutuhan pelanggan, rumah sakit kurang memberikan benefit bagi pelanggan, atau dapat dikatakan bahwa prinsip keunggulan bersaing belum sepenuhnya diterapkan di rumah sakit.

Industri rumah sakit saat ini bukan lagi semata-mata penyediaan layanan publik, namun sudah menjadi ranah komersial. Pemerintah merangsang swasta untuk berinvestasi di industri rumah sakit di Indonesia dalam beberapa tahun ini. Peningkatan jumlah yang terjadi menunjukkan bahwa industri ini memiliki daya tarik pasar yang cukup menarik.Tingginya daya tarik pasar juga dipicu oleh regulasi dalam hal investasi untuk mendirikan rumah sakit yang semakin mudah. Menilik keadaan tersebut, apabila kita tidak unggul dalam bersaing posisi rumah sakit kita dapat menjadi laiknya "tamu" di negeri sendiri.

Produk rumah sakit mencakup elemen teknologi penunjang medis, keahlian klinis maupun efisiensi waktu dan biaya (Berkowitz, 2011). Pada kenyataannya, teknologi tinggi dan keterbatasan jumlah dokter spesialis memang menjadi kendala umum rumah sakit. Mahalnya biaya teknologi menyebabkan rumah sakit enggan untuk investasi di bidang teknologi. Fenomena tersebut menunjukkan bahwa rumah sakit belum mengolah sumber daya yang ada untuk tampil sesuai kebutuhan pelanggan namun unik dan sulit ditiru.

Tingginya daya tarik pasar seharusnya memberikan kemanfaatan maksimal bagi rumah sakit non pemerintah di Provinsi Jawa Barat. Dibukanya kran investasi asing oleh Pemerintah, seyogyanya diantisipasi dengan membangun keunggulan bersaing melalui kreasi nilai dan pengembangan sumber daya yang unik. Namun demikian, fenomena yang diuraikan dalam latar belakang di atas menunjukkan bahwa keunikan sumber daya dan kreasi nilai yang dibangun rumah sakit belum mampu digunakan sebagai pembentuk keunggulan bersaing yang berujung pada tercapainya kinerja rumah sakit yang optimal.

\section{Tujuan Penelitian}

Untuk menganalisis daya tarik pasar, kreasi nilai, sumber daya yang unik, unggul dalam bersaing dan kepuasan pelanggan, kepuasan karyawan, operasional dan keuangan (kinerja) rumah sakit umum swasta di Provinsi Jawa Barat, serta mengetahui seberapa besar pengaruh daya tarik pasar, kreasi nilai dan sumber daya yang unik terhadap keunggulan bersaing parsial maupun bersama-sama. Penelitian juga ditujukan untuk menguji seberapa besar pengaruh daya tarik pasar, kreasi nilai dan sumber daya yang unik terhadap kinerja melalui unggul dalam bersaing.

\section{TINJAUAN PUSTAKA}

Banyak ahli dan institusi pemasaran mengungkap konsep tentang daya tarik pasar (market attractiveness). General Electrics/ McKinsey Matrix, merupakan konsep dari McKinsey yang menjadi rujukan utama untuk pengembangan konsep tentang daya tarik pasar. Konsep ini merupakan konsep spesifik untuk mengevaluasi peluang investasi yang diikembangkan pada awal abad 17 dan saat ini masih secara luas digunakan untuk menganalisi skenario persaingan bisnis. Untuk mengukur daya tarik pasar, Walker (2004) mengajukan beberapa indikator daya tarik pasar yaitu besar pasar, perkembangan pasar, tingkat persaingan, level harga, keuntungan, sistim informasi dan teknik, modern, serta regulasi Pemerintah.

Best (2009) mengatakan bahwa daya tarik pasar terukur melalui besarnya pasar $(30 \%)$, tingkat persaingan (40\%) dan peluang pasar (30\%). Komponen daya tarik pasar adalah ukuran pasar, 
pertumbuhan pasar dan kekuatan pembeli; komponen intensitas persaingan adalah banyaknya pesaing, harga pesaing dan kemudahan untuk masuk dalam arena kompetisi ini sedangkan komponen akses pasar adalah kedekatan dengan pelanggan, akses ke distributor dan sales requirement.

Daya tarik pasar merupakan salah satu dimensi dalam konsep GE Matrix, sebuah model multidimensional untuk merumuskan strategi korporasi. Daya tarik pasar dalam kerangka strategi bersaing model GE Matrix sering digunakan untuk menilai seberapa tinggi minat pebisnis memasuki pasar suatu industri. Semakin tinggi daya tarik pasar, semakin tinggi kecenderungan minat investasi pada industri tersebut.

Menurut Dafny (2005), dengan melihat tingginya kebutuhan pasien (daya tarik pasar) baik rendah, sedang maupun tinggi terutama sedang, maka peningkatan kualitas produk, pengalaman dan produk yang unik merupakan strategi investasi sebagai upaya untuk menghalangi pesaing memasuki industri (rumah sakit).

Kreasi nilai merupakan frase yang sering digunakan dalam kajian-kajian manajemen jasa. Dalam kajian-kajian terkini, proses penciptaan nilai bukanlah proses tunggal yang dilakukan oleh perusahaan saja, namun justru peran pelanggan sangat penting dan mendasar. Beberapa ahli telah menggunakan istilah tersebut untuk menggambarkan konsep nilai dalam kajian mereka, seperti Normann dan Ramirez (1993), Ramirez (1999), Prahalad dan Ramaswamy (2004), Vargo dan Lusch (2004), dan Grönroos (2006).

Normann dan Ramirez (1993) mengungkap bahwa pemikiran tradisional tentang value didasarkan pada asumsi-asumsi dan model ekonomi industri. Dalam pandangan ini, setiap perusahaan menempati suatu posisi dalam rantai nilai. Perusahaan tersebut tergantung pada pemasok untuk input dan kemudian menambahkan nilai kedalam input tersebut sebelum mengirimnya kepada perusahaan lain atau pelanggan dalam rantai nilai berikutnya. Strategi dalam model ini merupakan seni untuk menempatkan perusahaan pada tempat yang tepat dalam rantai nilai, yakni bisnis yang benar, produk yang tepat, segmen pasar yang sesuai dan aktivitas penambahan nilai yang tepat. Akan tetapi, dalam lingkungan yang tingkat persaingannya semakin tinggi, logika mendasar tentang penciptaan nilai (value creation) tersebut juga berubah dan rumusan strategi yang jelas dan bersifat simultan menjadi suatu hal yang mendasar. Prinsip perumusan strategi adalah bahwa tujuan perusahaan bukanlah untuk menciptakan nilai bagi pelanggan, namun memobilisasi pelanggan untuk menciptakan nilai mereka sendiri dari berbagai produk/jasa yang ditawarkan perusahaan (Normann dan Ramirez, 1993).

Sejalan dengan perspektif tentang kreasi nilai di atas, Vargo dan Lusch (2004) juga menyampaikan pandangan bahwa perusahaan hanya dapat menawarkan usulan tentang value, namun keputusan terakhir tentang value itu sendiri dan bagaimana mereka terlibat dalam proses penciptaan value tetap ada pada pelanggan. Keberhasilan perusahaan tidak ditentukan oleh bagaimana dia memberikan service yang efisien dan solusi standar kepada pelanggan, tetapi oleh bagaimana pelanggan dapat dengan mudah mendapatkan pelayanan solutif yang efisien melalui keterlibatannya dalam proses penciptaan nilai (Vargo dan Lusch, 2004).

Dalam industri rumah sakit, kenyamanan fisik dan keramahan terhadap pasien akan mengurangi ketidakpuasan pelanggan, namun demikian, value creation yang sebenarnya tidak dapat terbentuk tanpa adanya dialog yang membentuk dan melanggengkan hubungan antara pasien dengan dokter/perawatnya (Lindqvist dan Persson dalam Nordgren, 2009). Pengalaman pasien dalam perawatan dapat dikaitkan dengan rasa percayanya dalam membangun hubungan dengan rumah sakit (Nordgren dan Fridlund dalam Nordgren, 2009).

Value creation dapat didekati dengan kajian interaksi antara dokter dengan pasien. Proses penciptaan nilai pelanggan terbangun saat pertama kali pasien melakukan kontak dengan layanan medis. Bagi pasien, dapat menemui dokter sesegera mungkin sangatlah penting, dan inilah wujud dari aksesibilitas dalam penciptaan nilai. Proses kreasi nilai berlanjut kala pasien dan dokter berdialog untuk mengetahui penyakit atau penyebab masalah kesehatan pasien. Pasien menyampaikan keluhan kondisi kesehatannya, dokter mendengar, menggali lebih banyak informasi dan observasi, memberikan informasi yang relevan dan menuliskan resep. Ini merupakan proses dialog yang pada akhirnya akan menanamkan pengetahuan bagi pasien tentang penyakitnya, sedangkan dokter bertanggung jawab atas hasil pemeriksaannya, diagnosis, dan proposisi tindakan medisnya (Nordgren 2009).

Nordgren (2009) menekankan bahwa pembahasan tentang value creation dalam pelayanan kesehatan hendaknya didasarkan pada perspektif pelanggan/pasien. Value tercipta dalam proses interaksi pasien dengan doktert. Produktivitas service dalam industri rumah sakit harus mencakup nilai-nilai seperti pengalaman kesehatan pasien, kualitas hidup, penurunan waktu tunggu dan aksesibilitas, keyakinan, informasi, terhindarnya dari penderitaan dan kematian. 
Menurut Dafny (2005) dengan pertimbangan banyaknya kebutuhan pasien (daya tarik pasar) rendah, sedang dan tinggi, terutama sedang, maka peningkatan kualitas produk, pengalaman dan produk yang unik merupakan strategi investasi sebagai upaya untuk menghalangi pesaing memasuki industri (rumah sakit).

Menurut Huang (2007), untuk memenangkan keunggulan bersaing, hal yang sangat mendasar dalam bisnis, yakni kreasi nilai, perlu dilakukan. Porter menekankan pentingnya kreasi nilai dalam mengelola proses rantai nilai (value chain). Untuk itu sangat penting melakukan kreasi nilai yang komunikatif (Lars Nordgren, 2009). Para petugas medis, para medis harus memberikan informasi yang personal untuk masing-masing pelanggan/pasien. Koordinasi lintas bidang, jadwal praktek/operasi dan kompetensi harus diperhatikan. Produk dalam industri rumah sakit harus menciptakan nilai dalam kualitas hidup pasien, mengurangi waktu tunggu, kemudahan untuk dihubungi, kepercayaan, mudah mendapatkan informasi, menghindari penderitaan dan kematian. Sistem pendukung yang baik sangat dibutuhkan dalam industri ini.

Sesuatu dikatakan unik jika pesaing sulit untuk melakukan imitasi. Porter (1985) menyatakan bahwa perusahaan akan berbeda dari pesaingnya jika ia bisa memberikan sesuatu yang unik dan bernilai bagi pelanggannya. Diferensiasi memungkinkan perusahaan untuk menetapkan harga premium, menjual lebih banyak, dan bahkan mendorong terbangunnya kinerja unggul bagi perusahaan (Porter, 1985).

Keunikan sumber daya dalam industri layanan kesehatan dapat dikelompokkan menjadi tiga yaitu berbasis produk, berbasis pasar, dan berbasis biaya (Berkowitz, 2011). Keunikan rumah sakit dapat diwujudkan melalui diferensiasi layanan yang dibangun melalui kemampuan teknologinya, keahlian tenaga medisnya, citra atau jaringannya. Keunikan juga bisa dibangun melalui segmen yang lebih terarah, fokus pada layanan atau geografis tertentu. Dari sisi biaya, efisiensi operasi, pengendalian biaya, kurve belajar dan subsidi pemerintah juga bisa menjadi sumber keunikan suatu rumah sakit.

Sumber daya adalah modal, citra, strategi, ilmu dan sebagainya yang dipakai oleh para manajer pada saat yang sama dan hasil yang berbeda (Banarjee, 2003). Sumber daya harus value, unik dan sulit diimitasi oleh pesaing. Keunikan sumber daya adalah hal yang unik dalam internal perusahaan dimana sulit ditiru oleh pesaing (Linda E. Swayne, 2006).
Keunikan merupakan komponen penting pembentuk keunggulan bersaing. Keunikan dapat dibangun melalui aktivitas inti maupun aktivitas pendukung (Porter, 1985). Suatu perusahaan harus unik dibanding pesaingnya agar memiliki keunggulan bersaing. Keunikan tidak cukup hanya berupa slogan, tetapi harus benar-benar berupa sesuatu yang "kebal" dari imitasi oleh pesaing. Hal tersebut dapat dicontohkan sebagai berikut: penggunaan alat medical record elektronik pada waktu tertentu bisa menjadi sumber keunikan karena biaya pengadaan alat yang besar sehingga membutuhkan dana besar, perubahan budaya, dan pelatihan tenaga paramedis serta disiplin entri data secara ketat sehingga pesaing sulit untuk meniru penggunaan alat tersebut (Berkowitz, 2011).

Sedangkan menurut Barney 2007, untuk terus-menerus unggul dalam bersaing perusahaan harus memiliki value sulit diimitasi dan sulit diganti.

Citra bagi rumah sakit memegang peran penting seiring dengan meningkatnya persaingan dalam industri perawatan kesehatan, rumah sakit salah satunya. Citra dibangun melalui suatu proses dengan tujuan utama terbentuknya ekuitas merk rumah sakit, yakni persepsi rumah sakit di mata dokter, pasien, dan pihak-pihak yang berkepentingan dengan rumah sakit. Pencitraan umumnya dilakukan dengan memberikan layanan berkualitas secara konsisten, memelihara hubungan dengan pelanggan, dan menyampaikan informasi secara konsisten dan bermakna. Identitas suatu rumah sakit akan bernilai bila dikenal secara luas, unik, dan bernilai bagi pelanggan (Speak, 1996). Layanan yang berkualitas dapat dilihat dari reputasi yang baik dan rekomendasi dari dokter yang dapat dipercaya (Swayne, 2006).

Kelangkaan digunakan untuk membangun keunggulan bersaing melalui pengembangan produk layanan atau kepemilikan sumber daya yang mahal, membutuhkan keahlian sangat spesifik, dan atau memiliki segmen sangat terbatas. Cara ini dilakukan agar pesaing "tidak tertarik" untuk berkompetisi karena mahal atau dipandang pasarnya tidak menarik (Tuckman dan Chang, 1986).

Michael Porter adalah satu diantara beberapa peletak dasar manajemen strategis sebagai salah satu disiplin ilmu yang diakui. Porter telah memperkokoh konsep strategis dengan basis teori yang kuat namun tetap relevan untuk diterapkan (Stonehouse, 2007).

Menurut Porter unggul dalam bersaing ditentukan oleh posisi relatif perusahaan dalam industri tersebut. Posisi tersebut menunjukkan keuntungan suatu perusahaan berada lebih besar atau lebih kecil dari average. Unggul dalam bersaing 
berarti efisiensi (biaya rendah) dan tampil beda dalam five forces porter (Porter, 1985: 11).

Feurer dan Chaharbaghi (1994) menyatakan bahwa untuk mendefinisikan keunggulan bersaing, atau daya saing (competitiveness) hendaknya didasarkan pada keberadaan (raison d'etre) perusahaan dan pemain kunci yang menentukan hidup perusahaan. Sedangkan menurut Walker (2004), tujuan unggul dalam bersaing adalah perusahaan memberikan value dan efisiensi yang lebih dibanding pesaing. (Walker, 2004: 17).

Harga masih tetap menjadi salah satu basis persaingan disamping basis yang lain dalam industri kesehatan sebagaimana basis-basis yang lain seperti pilihan konsumen terhadap rumah sakit, akses, gaya perawatan, dan kualitas teknis perawatan (Miller, 1996), meski Porter menekankan bahwa persaingan pada industri perawatan kesehatan harus fokus kepada value bagi pasien (Porter dan Teisberg, 2006). Porter dan Teisberg (2006) menggambarkannya dalam garis produktivitas (productivity frontier) yang menunjukkan value maksimum yang diberikan perusahaan pada tingkat biaya tertentu, menggunakan teknologi tertentu, dan ketrampilan dan juga sumber daya yang lain tertentu.

Teridentifikasi delapan atribut kualitas pelayanan rumah sakit; rasa hormat dan peduli, efektivitas dan kontinuitas, kesesuaian, informasi, efisiensi, efektivitas menu, impresi petugas, dan keberagaman staf rumah sakit (Sower dkk, 2001).

Perkembangan perumahsakitan pada era globalisasi membutuhkan rambu-rambu yang jelas agar pelayanan yang diberikan di rumah sakit dapat berkualitas serta dijalankan sesuai etik dan profesional. Metoda yang digunakan sampai saat ini belum memperoleh kesepakatan, namun paling tidak ada beberapa macam yang dapat digunakan, antara lain kepuasan pasien, kepuasan karyawan, tingkat hunian rumah sakit, rata-rata hari rawat di rumah sakit, angka kematian dan rasio antara biaya dengan sisa hasil usaha.

Pengukuran kinerja diperlukan karena merupakan konsep sentral dari peningkatan kualitas rumah sakit (Shaw, 2003). Kinerja berkorelasi dengan pencapaian nilai dari pasien, tenaga medis dan paramedis, dan regulasi bidang rumah sakit.

Dalam industri rumah sakit Kessler dan Mylod (2000) mengemukakan indikator kepuasan pelanggan yaitu puas terhadap tempat, kepuasan karyawan, puas terhadap proses dan puas secara menyeluruh (Kessler dan Mylod, 2011). Kepuasan terhadap proses menunjukkan persepsi pelanggan terhadap proses, mulai dari pendafataran, pemeriksaan dan pengobatan, sampai dengan penyelesaian administrasi pelayanan. Kepuasan terhadap tempat menunjukkan persepsi pelanggan terhadap ruang perawatan dan menu makanan, sedangkan kepuasan terhadap karyawan menunjukkan persepsi pelanggan terhadap sikap dan pelayanan dokter dan tenaga paramedis. Secara keseluruhan, kepuasan pelanggan ditunjukkan oleh loyalitas pelanggan terhadap rumah sakit.

Kepuasan karyawan dapat diukur dari beberapa indikator. Menurut Chiu, Lin dan Hsiao (2005), ada dua indikator utama untuk mengukur kepuasan karyawan di industri rumah sakit; turnover karyawan adan komitmen organisasi. Turnover juga dapat diukur dari tingkat loyalitas karyawan kepada rumah sakit, sedangkan dari sisi komitmen organisasi, kepuasan dapat diukur dari kesediaan karyawan untuk ditempatkan pada unit manapun di rumah sakit, perasaan bangga sebagai karyawan rumah sakit, dan kepuasan secara umum.

\section{METODE PENELITIAN}

Sifat penelitian deskriptif dan verifikatif. Deskriptif untuk mendapatkan gambaran tentang daya tarik pasar, kreasi nilai, sumber daya yang unik, unggul dalam bersaing, dan kinerja rumah sakit. Sedangkan verifikatif merupakan gambaran hubungan diantara variabel setelah diuji hipotesisnya.

\section{Sumber dan Cara Penentuan Data}

Didapat dari data primer dan data sekunder. Yang merupakan data primer adalah data dari manajemen rumah sakit. Sedangkan data sekunder dari berbagai sumber seperti Dinas Kesehatan Provinsi Jawa Barat, BPS, dan sumber-sumber lain yang relevan.

Unit analisis adalah rumah sakit umum swasta di Provinsi Jawa Barat. Berdasar data dari Dinas Kesehatan Provinsi Jabar, jumlah rumah sakit umum swasta Provinsi Jawa Barat adalah 141. Sedangkan unit observasi adalah bidang keuangan dan umum, poliklinik, rawat inap, unit gawat darurat, farmasi, serta laboratorium. Maka setiap unit analisis diwakili oleh 6 responden.

\section{Variabel Operasional}

Variabel daya tarik pasar merupakan kemenarikan untuk mendirikan rumah sakit. Berdimensi kekuatan pasar, lingkungan kompetisi rumah sakit, serta kemudahan mendapatkan pelayanan.

Variabel kreasi nilai merupakan upaya yang dibangun melalui keterlibatan pelanggan dengan rumah sakit dalam rangka menciptakan nilai yang tinggi bagi pelanggan. Memiliki dimensi dialog pelanggan dengan tenaga medis/paramedis, akses 
komunikasi pelanggan dengan rumah sakit, transparansi informasi dari rumah sakit kepada pelanggan

Variabel keunikan sumber daya merupakan perbedaan, kelangkaan dan tingkat inimitabilitas suber daya. Keunikan sumber daya memiliki dimensi berbasis produk rumah sakit, kelangkaan dan in-imitabilitas. Variabel keunggulan bersaing merupakan kemampuan rumah sakit untuk memberikan value yang tinggi sekaligus dengan efisiensi biaya. Keunggulan bersaing memiliki dimensi value dan biaya.
Variabel kinerja rumah sakit merupakan hasil pencapaian kinerja rumah sakit dalam menjalankan visi dan misinya. Kinerja rumah sakit memiliki dimensi kepuasan pelanggan, kepuasan karyawan, operasional, dan keuangan.

\section{Model Penelitian}

Untuk menguji hipotesis verifikatif digunakan model persamaan struktural yang diturunkan dari model jalur sebagaimana terlihat dalam gambar berikut:

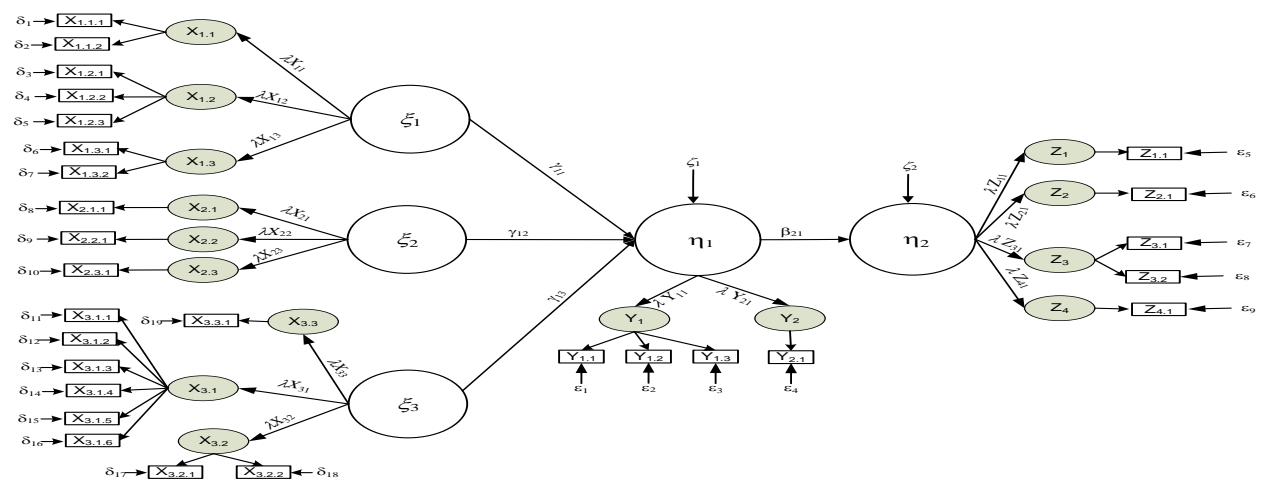

\section{Gambar 1. Model Persamaan Struktural Penelitian}

\section{HASIL DAN PEMBAHASAN}

\section{Pengujian Deskriptif}

Hasil pengujian hipotesis deskriptif menunjukkan penolakan seluruh hipotesis yang diajukan. Dari sisi daya tarik tarik pasar, indeks penilaian sebesar 656,83, masih terdapat gap dengan indeks yang menjadi kriteria penerimaan hipotesis (yakni 810) sebesar 18,91\%. Belum maksimalnya daya tarik pasar ini, selayaknya membuat pihak rumah sakit memperhatikan upaya persaingan sesuai Dafny (2005) bahwa peningkatan kualitas produk, pengalaman dan produk yang unik merupakan strategi investasi sebagai upaya untuk menghalangi pesaing memasuki industri. Kecenderungan menariknya daya tarik pasar rumah sakit umum swasta di Provinsi Jawa Barat ini dapat juga menjadi peluang dan ancaman sebagaimana dikatakan oleh Hill \& Jones, 2.009 yaitu peluang jika perusahaan unggul dalam lingkungan eksternal.

Dari sisi kreasi nilai, rumah sakit umum swasta di Provinsi Jawa Barat masih belum melakukan kreasi nilai secara optimal. Hal ini ditunjukkan oleh indeks penilaian sebesar 61,33 sehingga masih terdapat gap sebesar $24,53 \%$ dari indeks maksimal. Penolakan hipotesis menunjukkan bahwa keterlibatan pelanggan dalam penciptaan layanan di rumah sakit sakit umum di Provinsi Jawa Barat yang merupakan inti pelayanan rumah sakit belum maksimal. Sebuah diagnosa dapat dilakukan dengan baik apabila pelanggan (pasien) terlibat penuh dan interaktif dengan rumah sakit.

Keterlibatan pelanggan sebagai co-creator nilai dapat mendorong timbulnya pengalaman pelanggan, sebagaimana dikemukakan oleh Prahalad dan Ramaswamy tentang pentingnya peran pelanggan dalam penciptaan nilai [(Ramirez, 1999); (Prahalad dan Ramaswamy, 2004)]. Belum optimalnya dialog pelanggan dengan pemberi pelayanan kesehatan kemungkinan disebabkan belum maksimalnya hasil yang dicapai rumah sakit dalam mendorong keterlibatan pasien dalam penciptaan layanan.

Dari sisi keunikan sumber daya, sumber daya rumah sakit umum di Provinsi Jawa Barat belum unik. Hal ini ditunjukkan oleh indeks penilaian sebesar 650,67 sehingga masih terdapat gap sebesar 19,67 dari indeks maksimal. Belum uniknya sumber daya rumah sakit umum swasta di Provinsi Jawa Barat tersebut belum memenuhi kriteria sumber daya menurut Barney (2007), yakni unik baik dari sisi nilai, kelangkaan, dan sulit ditiru. Dalam tataran implementasi, untuk dapat memberikan pelayanan 
yang optimal, rumah sakit harus fokus pada keunikan yang tidak mudah ditiru.

Belum uniknya sumber daya tersebut diatas sesuai pernyataan Berkowitz (2011) yaitu keunikan sumber daya berbasis produk dapat diinvestigasi dari kapabilitas teknologi, kualifikasi dokter, citra, pemeliharaan hubungan pelanggan, konsistensi informasi, dan jaringan rumah sakit. Dari sisi kelangkaan, upaya rumah sakit umum di Provinsi Jawa Barat membangun barrier melalui pengembangan produk layanan atau kepemilikan sumber daya yang mahal, membutuhkan keahlian sangat spesifik, dan atau memiliki segmen sangat terbatas, sebagaimana dinyatakan oleh Tuckman dan Chang (1986), belum maksimal.

Dari sisi keunggulan bersaing, gap variabel keunggulan bersaing sebesar 24,04\% mencerminkan belum tingginya keunggulan bersaing dan value rumah sakit umum swasta di Provinsi Jawa Barat. Merupakan implementasi pencapaian kinerja yang belum maksimal, belum sejalan dengan pendapat Loeppke (2008) bahwa disain pelayanan perawatan kesehatan berbasis value menjadi keharusan bagi institusi kesehatan, apalagi adanya kesadaran masyarakat tentang pentingnya pencegahan karena biaya yang jauh lebih murah daripada harus berobat (Loeppke, 2008).

Rumah sakit umum di Provinsi Jawa Barat seharusnya mampu meningkatkan kehandalannya seperti ketepatan janji, kesesuaian pelayanan, kepedulian, ketepatan diagnosa oleh dokter, dan kesesuaian pelayanan rumah sakit yang lain. Demikian juga dari indikator efisiensi biaya, rumah sakit umum swasta di Provinsi Jawa Barat masih harus meningkatkan efisiensi biaya operasionalnya agar dapat unggul dalam bersaing.

\section{Pengujian Verifikatif}

Hipotesis verifikatif pertama yang akan diuji adalah seberapa besar pengaruh daya tarik pasar, kreasi nilai serta sumber daya yang unik kepada keunggulan bersaing secara bersama-sama dan parsial. Secara bersama-sama, pengujian melalui statistik uji F dengan ketentuan terima Ho jika hasil $\mathrm{F}_{\text {hitung }}>\mathrm{F}_{\text {tabel. }}$. Dari tabel $\mathrm{F}$ dengan derajat kebebasan (3; 158) didapat $F_{\text {tabel }}$ senilai 2,662. Sedangkan hasil penghitungan nili $F$ sebesar 66,489. Dengan demikian maka $\mathrm{H}_{1}$ diterima. Disimpulkan daya tarik pasar, kreasi nilai serta sumber daya yang unik secara bersama-sama memiliki pengaruh kepada keunggulan bersaing rumah sakit umum swasta di Provinsi Jawa Barat.

Untuk membuktikan apakah daya tarik pasar, kreasi nilai dan sumber daya yang unik berpengaruh kepada unggul dalam bersaing maka dilakukan pengujian hipotesis parsial. Kriteria pengujian untuk uji hipotesis tersebut adalah tolah $\mathrm{H}_{0}$ jika $\mathrm{t}_{\text {hitung }}<\mathrm{t}_{\text {tabel }}$. Nilai $\mathrm{t}_{\text {tabel }}$ yang digunakan dalam hal ini untuk tingkat signifikan 95\%, yakni 1,96.

Diantara ketiga variabel eksogen, keunikan sumber daya berpengaruh paling besar kepada keunggulan dalam bersaing rumah sakit umum swasta di Provinsi Jawa Barat, yakni 28,8\% dengan $t_{\text {hitung }}$ sebesar 9,108. Sebaliknya kreasi nilai berpengaruh paling kecil kepada keunggulan dalam bersaing 7,2\% dengan $t_{\text {hitung }}$ sebesar 1,513. Sedangkan daya tarik pasar berpengaruh kepada keunggulan dalam bersaing senilai 19,8\% dengan $t_{\text {hitung }}$ sebesar 4,092. Dengan demikian, secara parsial hanya kreasi nilai yang hipotesisnya ditolak.

Pengaruh positif keunikan sumber daya terhadap keunggulan bersaing sejalan dengan pernyataan Barney (2007). Menurut Barney, agar unggul dalam bersaing perusahaan harus memiliki value yaitu mampu mengolah peluang yang ada. Sumber daya harus unik dan sulit ditiru serta tidak tergantikan.

Penolakan hipotesis yang menyatakan bahwa kreasi nilai secara parsial berpengaruh terhadap keunggulan bersaing menunjukkan bahwa variabilitas kreasi nilai ternyata tidak bisa menjelaskan variabilitas keunggulan bersaing rumah sakit umum swasta di Provinsi Jawa Barat. Tidak signifikannya pengaruh variabel kreasi nilai secara parsial terhadap variabel keunggulan bersaing juga dapat diartikan bahwa meskipun secara deskriptif upaya kreasi nilai yang dilakukan telah optimal, namun secara uji verifikatif tidak berdampak terhadap keunggulan bersaing. Dialog antara pasien dengan dokter/paramedis merupakan sebuah keharusan.

Keterlibatan pasien dalam proses diagnosa, pengobatan, dan pelayanan rumah sakit adalah sebuah kelaziman dan kepatuhan terhadap undang-undang, sehingga kreasi nilai bukan lagi merupakan faktor yang dapat membentuk keunggulan bersaing rumah sakit umum swasta di Provinsi Jawa Barat. Demikian juga indikator-indikator kreasi nilai yang lain seperti akses dan transparansi informasi.

Hipotesis verifikatif kedua yaitu besar pengaruh daya tarik pasar, kreasi nilai serta sumber daya yang unik kepada kinerja rumah sakit umum swasta di Provinsi Jawa Barat melalui keunggulan bersaing. Untuk pengujian ini tergambar sebagai berikut: 


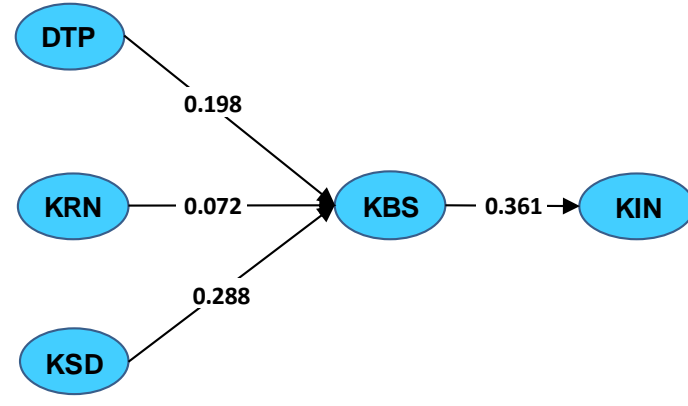

Gambar 2

\section{Diagram Jalur Besar Pengaruh Masing-Masing Variabel}

Sehingga hitungan pengaruh variabel independen kepada kinerja rumah sakit melalui keungulan bersaing adalah:

- Besar pengaruh daya tarik pasar kepada kinerja rumah sakit lewat unggul dalam bersaing = $0,198 \times 0,361=0,071(\mathbf{7 , 1 \%})$.

- Pengaruh kreasi nilai terhadap kinerja rumah sakit melalui keunggulan bersaing $=0,072 \times$ $0,361=0,026(\mathbf{2 , 6 \%})$.

- Pengaruh keunikan sumber daya terhadap kinerja rumah sakit melalui keunggulan bersaing $=0,288 \times 0,361=0,104(\mathbf{1 0 , 4 \%})$.

Dapat diambil kesimpulan yaitu unggul dalam bersaing dipengaruhi oleh daya tarik pasar, kreasi nilai, serta sumber daya yang unik. Tampak keunikan sumber daya memiliki pengaruh terbesar dibanding variabel lainnya. Hal ini sesuai dengan pendapat Porter dan John Kay bahwa keunikan merupakan komponen penting pembentuk keunggulan bersaing.Sumber daya yang digunakan harus memenuhi kriteria sumber daya yang unik baik dari sisi nilai, kelangkaan dan sulit ditiru (Barney, 2007)

\section{Pembahasan Pemecahan Masalah}

Untuk memecahkan permasalahan penelitian, perlu dilakukan langkah-langkah mulai dari pemetaan strategi, operasionalisasi strategi, rencana tindakan serta rencana evaluasi dan pengendalian. Ketiga langkah ini dirumuskan mengacu pada model rantai nilai dari Porter dan Teisberg (2006).

Untuk meningkatkan keunggulan bersaing, hal-hal yang harus dilakukan untuk meningkatkan keunggulan bersaing:

a. Optimalisasi keunikan sumber daya, melalui peningkatan citra.

b. Peningkatan daya tarik pasar melalui peningkatan kemampuan membayar biaya pelayanan rumah sakit dan pemahaman kebutuhan pelanggan. c. Peningkatan keterlibatan pelanggan dalam proses pelayanan kesehatan dan kemudahan menghubungi rumah sakit.

Sedangkan untuk meningkatkan kinerja rumah sakit umum di Provinsi Jawa Barat, aspek kepuasan karyawan dan pencapaian LOS ideal menjadi prioritas untuk ditingkatkan.

Secara operasional, upaya peningkatan keunggulan bersaing dan kinerja dilakukan pada enam unit bisnis di rumah sakit umum di Provinsi Jawa Barat yaitu farmasi, UGD, rawat jalan, rawat inap, laboratorium, dan keuangan. Evaluasi dan pengendalian perlu dilakukan secara terus menerus mengingat kondisi eksternal dan internal yang tidak statis. Adaptasi harus segera dilakukan, disesuaikan dengan kebutuhan pelanggan agar dapat tercapai kinerja dan keunggulan bersaing yang tinggi.

\section{KESIMPULAN DAN SARAN}

\section{Kesimpulan}

Secara deskriptif, daya tarik pasar rumah sakit umum swasta di Provinsi Jawa Barat belum menarik, kreasi nilai yang dilakukan oleh rumah sakit umum swasta di Provinsi Jawa Barat belum optimal, dan sumber daya rumah sakit umum swasta di Provinsi Jawa Barat belum unik. Disamping itu, keunggulan bersaing maupun kinerja rumah sakit umum swasta di Provinsi Jawa Barat belum tinggi.

Daya tarik pasar, kreasi nilai, serta sumber daya yang unik rumah sakit umum swasta di Provinsi Jawa Barat baik parsial maupun simultan berpengaruh terhadap keunggulan bersaing. Secara parsial, keunikan sumber daya memiliki pengaruh paling kuat terhadap keunggulan bersaing. Daya tarik pasar, kreasi nilai serta sumber daya yang unik juga berpengaruh kepada kinerja rumah sakit umum swasta di Provinsi Jawa Barat melalui keunggulan bersaing.

\section{Saran}

Rumah sakit umum swasta di Provinsi Jawa Barat disarankan untuk mengoptimalkan kreasi nilai, meningkatkan keunikan sumber daya, meningkatkan keunggulan bersaing dan juga kinerja melalui antara lain peningkatan efisiensi dan respon farmasi, peningkatan aksesibilitas kecepatan, fleksibilitas, dan kehandalan pelayanan unit gawat darurat, peningkatan ketepatan jadwal dan minimisasi pembatalan oleh dokter dan pasien, efisiensi jalur melalui integrasi sistem antrian, pencapaian BOR (Bed Occupation Rate) dan LOS (Length of Stay) ideal melalui peningkatan efisiensi operasi dan marketing, peningkatan kualitas pelayanan di laboratorium dan peningkatan 
produktivitas dan efisiensi unit keuangan dan administrasi. Penelitian selanjutnya disarankan agar melibatkan variabel lain, seperti model kepemimpinan atau perilaku organisasi.

\section{DAFTAR PUSTAKA}

Barney, J. B. 2007. Resource-Based Theory: Creating Sustaining Competitive Advantage. Oxford University Press.

Berkowitz, E. N. 2011. Essentials of Health Care Marketing, 3rd Ed. London: John \& Bartlett Learning, LLC.

Best, R. J. 2009. Portfolio Analysis and Strategic Market Planning. In R. J. Best, Market-Based Management: Growing Customer Value and Profitability, 5th ed., pp. 376-377. New Jersey: Prentice-Hall.

Chiu, Chou-Kang, Chi-Seng Chien, Chieh-Peng Lin, dan Ching Yun Hsiao. 2005. Understanding hospital employee job stress and tunrover intentions in a practical setting. Journal of Management Development, Vol. 24 No. 10, pp. 837-855.

Dafny, Leemore S. "Games Hospitals Play: Entry Deterrence in Hospital Procedure Markets." Journal of Economics \& Management Strategy, Vol. 14 No. 3, 2005: 513-542.

Ghazali, Imam. 2008. Structural Equation Modeling: Metode Alternatif Dengan Partial Least Square. Semarang: BP-Undip.

Grönroos, C. 2006. Adopting a service logic for marketing. Marketing Theory, Vol. 6, No. 3, pp. 317-333.

Hill, Charles W.L. 2009. Strategic Management: An Integrated Approach. $7^{\text {th }}$ ed. Ohio: Houghton Mifflin.

Huang, Xueli dan Ruosheng Zhang. 2007. The Art of Value Creation Strategy: Evidence from a Chinese state-owned enterprise. Chinese Management Studies, Vol. 1 No. 3, pp.180-197.

Hunger, David \& Wheelen Thomas. 2006. Manajemen Strategis, Penerbit Andi, Yogyakarta

Kessler, Daniel P. dan Deirdre Mylod. 2011. Does patient satisfaction affect patient loyalty? International Journal of Health Care Quality Assurance, Vol. 24 No. 4, pp. 266-273.

Loeppke, Ronald. 2008. The value of health and the power of prevention. International Journal of
Workplace Health Management, Vol. 1 No. 2, p. 95-108.

Nordgren, L. 2008. Value Creation in Health Care Services-Developing Service Productivity: Experiences from Sweden. International Journal of Public Sector Management, Vol. 22, No. 2, pp. 114-127.

Normann, R.D. 1993, Juli/Agustus. From Value Chain to Value Constellation: Designing Interactive Strategy. Harvard Business Review, Vol. 71 No. 4, pp. 65-77.

Parker, C. 2000. Performance Measurement. Work Study, Vol.49 No.2, pp. 63-66.

2006. Redefining Health Care: Creating Value-Based Competition on Results. Health Information Technology Symposium (pp. 1-27). Massachusetts : Massachusetts Institute of Technology.

Prahalad, C.K. dan Venkat Ramaswamy. 2004a. Co-creation Experiences: The Next Practice In Value Creation. Journal of Interactive Marketing, Vol. 18 No. 3, pp. 5-14.

$2004 b$.

Co-creating Unique Value With Customers. Strategy and Leadership, Vol. 32, No. 3, pp. 4-9.

Ramirez, Rafael . 1999. Value Co-Production: Intellectual Origins and Implications for Practice and Research. Strategic Management Journal, Vol. 20, pp. 49-65.

Sower, V., J. Duffy, W. Kilbourne, G. Kohers, dan P. Jones. 2001. The Dimension of Service Quality for Hospitals: Development and Uses of KQCAH Scale. Health Care Management Review, Vol. 26 No. 2, pp. 47-59.

Stonehouse, G. d. 2007. Competitive Advantage Revisited; Michael Porter on Strategy and Competitiveness. Journal of Management Inquiry, Vol. 16 No. 3, pp. 256-273.

Swayne, Linda E, W. Jack Duncan, Peter M.G. 2006. Strategic Management of Health Care Organization, Blackwell Publishing.

Vargo, S.L. dan Lusch, R.F. 2004. Evolving to a new dominant logic for marketing. Journal of Marketing, Vol. 68, pp. 1-17.

Walker, G. 2004. Modern Competitive Strategy. New York. McGraw-Hill. 